\title{
Sistem Informasi Booking Online Berbasis PHP dan Android Pada Dealer Mobil Pemium: Studi Kasus PT. XYZ
}

\author{
Riva Abdillah Aziz ${ }^{1)}$, Arfan Sansprayada ${ }^{2)}$,'Kartika Mariskhana ${ }^{3)}$ \\ ${ }^{1)}$ STMIK Nusa Mandiri Jakarta \\ 2) 3) Universitas Bina Sarana Informatika Jakarta \\ ${ }^{*}$ Correspondence Author: arfan.anp@ bsi.ac.id, Jakarta, Indonesia \\ DOI:https://doi.org/10.37012/jtik.v7i1.499
}

\begin{abstract}
Abstrak
Bagi para pengguna kendaraan roda empat, mendatangi dealer atau bengkel mobil untuk melakukan perbaikan atau perawatan kendaraannya merupakan salah satu hal yang paling menjenuhkan. Proses perbaikan atau perawatan yang lama merupakan alasan utama para pengguna tidak puas terhadap layanan bengkel. Hal tersebut dialami juga oleh PT. XYZ, sebuah perusahaan yang bergerak dibidang penjualan, perawatan, dan perbaikan mobil kelas premium. Oleh karena itu PT. XYZ ingin meminimalisir ketidak puasan tersebut dengan menyediakan sistem informasi booking online. Namun yang menjadi kendala adalah sistem booking online seperti apa yang cocok bagi PT. XYZ. Ada beberapa teknik yang digunakan untuk mendapatkan data penelitian yaitu: Observasi, Interview, dan Studi Pustaka. Hasil dari penelitian ini adalah, dengan sistem booking online berbasis android sangat membantu para customer dalam melakukan booking online dimanapun dan kapanpun sesuai kondisi, dengan cepat dan mudah. Sistem informasi berbasis android pada saat ini memang sudah menjadi kebutuhan yang tidak bisa dihindari, dan terbukti memberikan nilai tambah perusahaan di mata para customernya.
\end{abstract}

Kata Kunci: Sistem Informasi, Booking Online, Android

\begin{abstract}
For four-wheeled vehicle users, visiting a car dealer or repair shop to repair or maintain their vehicle is one of the most saturating things. The long repair or maintenance process is the main reason the users are not satisfied with the repair shop service. This is also experienced by PT. XYZ, a company engaged in the sale, maintenance and repair of premium class cars. Therefore, PT. XYZ wants to minimize this dissatisfaction by providing an online booking information system. However, the problem is what kind of online booking system is suitable for PT. XYZ. There are several techniques used to obtain research data, namely: Observation, Interview, and Literature Study. The results of this study are, with an online booking system based on Android, it is very helpful for customers in making online bookings wherever and whenever according to conditions, quickly and easily. Nowadays, Android-based information systems have become an inevitable necessity, and have proven to provide added value to the company in the eyes of its customers.
\end{abstract}

Keywords: Information System, Online Booking, Android

\section{PENDAHULUAN}

Bagi perusahaan yang core business nya adalah jasa, pelayanan yang sempurna kepada pelanggan adalah kunci sukses keberhasilan perusahaan. Dengan pelayanan atau service yang sempurna maka pelanggan kemungkinan besar akan loyal pada perusahaan tersebut. Selain itu kepuasan yang dirasakan oleh pelanggan bisa menjadi media promosi gratis bagi perusahaan ketika pelanggan tersebut menceritakan service excellent yang diterima kepadanya kepada rekan-rekannya. Hal ini bisa jadi sebagai media promosi melalui mulut kemulut (Word of Mouth). Word of Mouth ini memiliki kekuatan (The Power of Word of 
Mouth) promosi yang tidak dapat dipandang remeh. The Power of Word of Mouth sangat ampuh dalam meyakinkan konsumen, bahkan dalam sebuah penelitian disebutkan bahwa sekitar 70\% konsumen yang membeli produk adalah mereka yang mendapatkan rekomendasi dan informasi dari konsumen lain melalui promosi dari mulut ke mulut.

Padatnya aktivitas dan macetnya jalan-jalan di ibu kota membuat para pelanggan ingin kepastian waktu pelayanan yang diberikan oleh perusahaan jasa. Mereka tidak ingin berlama-lama menunggu hanya untuk sebuah panggilan antrian. Mereka tidak ingin menempuh jarak yang jauh serta menghabiskan waktu yang cukup lama, namun ketika sampai tujuan pelayanan sudah ditutup dikarenakan qouta jumlah pelanggan yang dilayanai sudah penuh. Hal tersebut membuat pelanggan jengkel.

Kejadian di atas tentu harus dihindari oleh sebuah perusahaan yang bergerak dibidang jasa, perusahaan dituntut se-informatif mungkin kepada pelanggan. Perusahaan harus menginformasikan apakah mereka dapat dilayani pada hari yang dipilihnya. Dengan kepastian yang diberikan oleh perusahaan jasa maka sudah tentu pelanggan akan merasa puas. Pelanggan dapat merencanakan hari apa untuk melakukan kunjungan ke perusahaan jasa tersebut, dan pelanggan dapat mengatur jadwalnya sesuai kebutahan.

Hal ini bukan suatu yang mustahil dilakukan oleh perusahaan jasa, terlebih di era digital saat ini yang makin hari makin canggih teknologi yang bermunculan. Dengan sangat pesatnya perkembangan teknologi saat ini, banyak pihak yang memanfaatkan kesempatan ini untuk membuat sistem informasi yang dapat membantu efektifitas dan efisiensi suatu aktifitas. Menurut Indrayasa (2015) memberikan batasan bahwa : Sistem adalah suatu jaringan kerja dari prosedur- prosedur yang saling berhubungan, berkumpul bersama- sama untuk melakukan suatu kegiatan atau untuk menyelesaikan suatu sasaran tertentu atau merupakan kumpulan dari elemen-elemen yang saling berinteraksi untuk mencapai suatu tujuan tersebut. Sedangkan informasi adalah data yang diolah menjadi bahan yang lebih berguna dan berarti bagi penerimanya.

Berkaitan pelayanan yang akan diberikan kepada para pelanggan, sistem informasi yang dapat digunakan oleh perusahaan yang bergerak dibidang jasa adalah sistem informasi booking online berbasis android. Dengan sistem informasi ini para pelanggan akan dengan mudah memilih waktu yang dikehendaki dimana dan kapanpun juga melalui mobile phone mereka. Sistem informasi booking online berbasis android dapat menjadi awal bagi para pelanggan mendapatkan pelayanan yang sempurna. Dengan sistem ini para pelanggan akan mendapatkan kepastian kapan mereka dapat dilayani. 
Salah satu jenis usaha yang membutuhkan sistem informasi ini adalah PT. XYZ yang bergerak dibidang automotive premium. Sebagai perusahaan automotive kelas premium sudah menjadi keharusan memberikan pelayanan se-excellent mungkin. Perusahaan dituntut tidak boleh mengecewakan pelanggannya yang merupakan pengguna kendaraan kelas atas. Perusahaan dituntut sebisa mungkin sedari awal memberikan gambaran bahwa pelayanan yang akan diberikan memang sekelas dengan kendaraan yang digunakan oleh mereka. Bisa dibayangkan jika baru melakukan registrasi saja sudah mengecewakan pasti yang terbayangkan dalam benak pelanggan adalah pelayanan yang akan diberikan bisa jadi mengecewakan.

Saat ini PT. XYZ dalam melayani para pelanggannya yang akan melakukan booking masih menggunakan metode lewat telepon, cara ini memang sudah membantu para pelanggan yang akan melakukan booking, namun pelanggan hanya dapat dilayani hanya pada jam kantor, sehingga hal ini menjadi kesulitan bagi para pelanggan yang akan melakukan booking perawatan atau perbaikan kendaraannya dimalam hari atau dihari libur.

Untuk mengatasi masalah tersebut diperlukan sistem informasi yang cepat dan tepat yang dapat digunakan kapanpun dan dimanapun dengan cepat dan mudah. Untuk keperluan booking service seperti yang diuraikan di atas maka dirancang sistem informasi booking online berbasiskan android. Pemilihan sistem booking online berbasiskan android ini tepat karena dengan sistem tersebut pelanggan dapat melakukan booking dimana dan kapanpun dengan mudah dan cepat.

\section{METODE}

Dalam teknik pengumpulan data tugas ini menggunakan beberapa teknik yaitu :

\section{Observasi}

Obervasi dilakukan dengan mendatangi langsung ke PT. XYZ, dalam proses observasi ini dilakuka pengamatan secara langsung untuk melihat dan memahami kebutuhan sistem yang diperlukan oleh PT. XYZ.

\section{Interview}

Setelah permasalahan yang ada pada PT. XYZ diketahui, maka untuk lebih mendalami permasalahan yang ada dilakukan interview kepada para karyawan yang berinteraksi langsung terhadap proses booking yang saat ini sedang berjalan dan karyawan-karyawan yang akan berinteraksi dengan sistem informasi online.

\section{Studi Pustaka}

Studi pustaka yang dilakukan dengan mengumpulkan data-data yang berhubungan dengan pembuatan sistem berbasiskan android dari buku-buku. Selain dari buku- 
buku, juga dikumpulkan data-data yang berhubungan dengan sistem informasi dan teknologi android dari internet.

Dalam pengembangan sistem, dilakukan beberapa kegiatan yaitu :

\section{Analisa Kebutuhan Sistem}

Dalam tahap ini, dilakukan analisis terhadap kebutuhan software yang cocok digunakan oleh PT. XYZ. Software ini nantinya digunakan untuk kebutuhan pemrosesan booking service kendaraan.

\section{Desain}

Tampilan antarmuka yang disajikan untuk pengguna yang ada pada android adalah terdapat tombol menu, form login, menu lupa password, menu registrasi, menu booking service, menu melihat status pengerjaan.

\section{Code Generation}

Bahasa pemrograman yang digunakan dalam pembuatan sistem booking service ini adalah android dengan menggunakan metode pemrograman terstruktur yang ditulis menggunakan tools android studio.

\section{Testing}

Pengujian sistem booking service berbasis androiod ini akan dilakukan dengan 2 tahap, pada tahap pertama akan diuji dengan menggunakan metode pengujian white box dimana sebagian tahap pengujian ini meliputi pengujian algoritma yang dibuat, baik pengujian secara sebagian ataupun secara keseluruhan. Dan yang kedua adalah melalui pengujian black box yaitu dengan cara memasukan input pada sistem informasi tersebut, dan hasilnya akan dianalisa apakah sudah sesuai dengan yang diharapkan atau belum.

\section{Support}

Sistem informasi booking service berbasis android ini dibangun dengan menggunakan bahasa pemrograman android berbasis java menggunakan tools aplikasi android studio berbasis windows 7. Hardware yang digunakan dalam membangun aplikasi ini adalah notebook dengan processor intel core i3 dengan memori 4 GB dan harddisk 500 GB.

Menurut Sukamto dan Shalahuddin (2013:133) UML (unified modeling language) yaitu standarisasi bahasa pemodelan untuk pembangunan perangkat lunak yang dibangun dengan menggunakan teknik pemrograman berorientasi objek.

UML merupakan bahasa visual untuk permodelan dan komunikasi mengenai sebuah sistem dengan menggunakan diagram dan teks-teks pendukung. Diagram berbentuk grafik yang menunjukkan simbol elemen model yang disusun untuk mengilustrasikan bagian atau 
aspek tertentu dari sistem. Sebuah diagram merupakan bagian dari suatu view tertentu dan ketika digambarkan biasanya dialokasikan untuk view tertentu. Adapun jenis diagram antara lain :

\section{Use Case Diagram}

Menurut Sukamto dan Shalahuddin (2013:155) "Use case atau diagram use case merupakan permodelan untuk kelakukan (behavior) sistem informasi yang akan dibuat. Use case mendeskripsikan sebuah interaksi antara satu atau lebih aktor dengan sistem informasi yang akan dibuat”.

\section{Activity Diagram}

Menurut Sukamto dan Shalahuddin (2013:161) "Diagram aktivitas atau activity diagram menggambarkan workflow (aliran kerja) atau aktivitas dari sebuah sistem atau proses bisnis atau menu yang ada pada perangkat lunak."

\section{Class Diagram}

Menurut Sukamto dan Shalahuddin (2013:141) "Diagram kelas atau class diagram menggambarkan struktur sistem dari segi pendefinisian kelas-kelas yang akan dibuat untuk membangun sistem. Kelas memiliki apa yang disebut atribut dan metode atau operasi."

\section{Sequence Diagram}

Menurut Sukamto dan Shalahuddin (2013:165) "Diagram sekuen menggambarkan kelakuan objek pada use case dengan mendeskripsikan waktu hidup objek dan message yang dikirimkan dan diterima antar objek. Oleh karena itu untuk menggambarkan diagram sekuen maka harus diketahui objek-objek yang terlibat dalam sebuah use case beserta metode-metode yang dimiliki kelas yang diintansiasi menjadi objek itu".

\section{HASIL DAN PEMBAHASAN}

Sistem Informasi booking online adalah sistem yang dirancang untuk memudahkan dan memberikan pelayanan yang lebih lagi kepada para customer pemilik kendaraan mobil untuk melakukan perbaikan atau perawatan mobilnya dengan cara melakukan booking terlebih dahulu secara online. Dengan sistem ini diharakan para customer dapat melakukan booking online melalui phoneselnya dimana dan kapanpun juga. Pada sistem ini, para customer dapat juga melihat status perbaikan kendaraannya.

Berkaitan hal tersebut, maka dibutuhkan beberapa spesifikasi menu, berikut adalah spesifikasi kebutuhan (system requirement) dari sistem informasi booking online: 
Halaman Admin:

A1. ADMIN dapat melakukan login

A2. ADMIN dapat mengelola data user

A3. ADMIN dapat melihat laporan data booking service

A4. ADMIN dapat melihat laporan data booking Pickup Service

A5. ADMIN dapat melihat laporan jadwal kuliah

Halaman Customer:

B1. Customer dapat melakukan Login

B2. Customer dapat melakukan booking service

B3. Customer dapat melakukan booking Pickup Service

B4. Customer dapat melihat status perbaikan kendaraanny

B5. Customer dapat melakukan reset password

Use case menggambarkan fungsionalitas sistem atau persyaratan-persyaratan yang harus dipenuhi dari pandangan pengguna. Diagram ini menggambarkan model lengkap tentang apa yang ada pada sistem, siapa yang berperan dalam sistem dan siapa yang berperan di luar sistem. Hal ini juga menggambarkan ruang lingkup organisasi, sehingga dapat dilihat apa atau siapa yang ada di luar organisasi dan sampai mana batasannya.

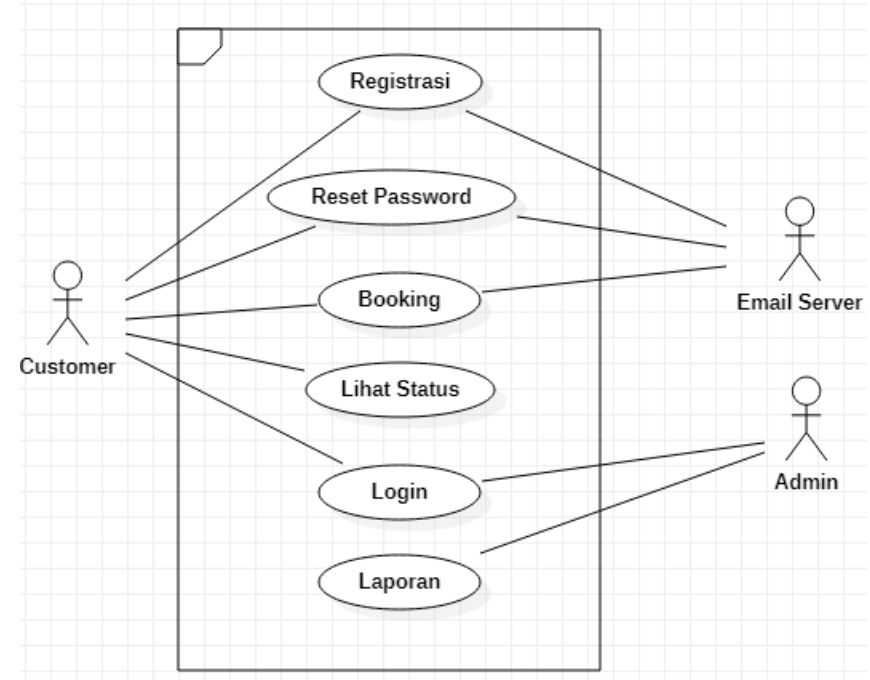

Gambar 1. Use Case Diagram

Berikut ini adalah Activity Diagram Login dan Registrasi Customer 


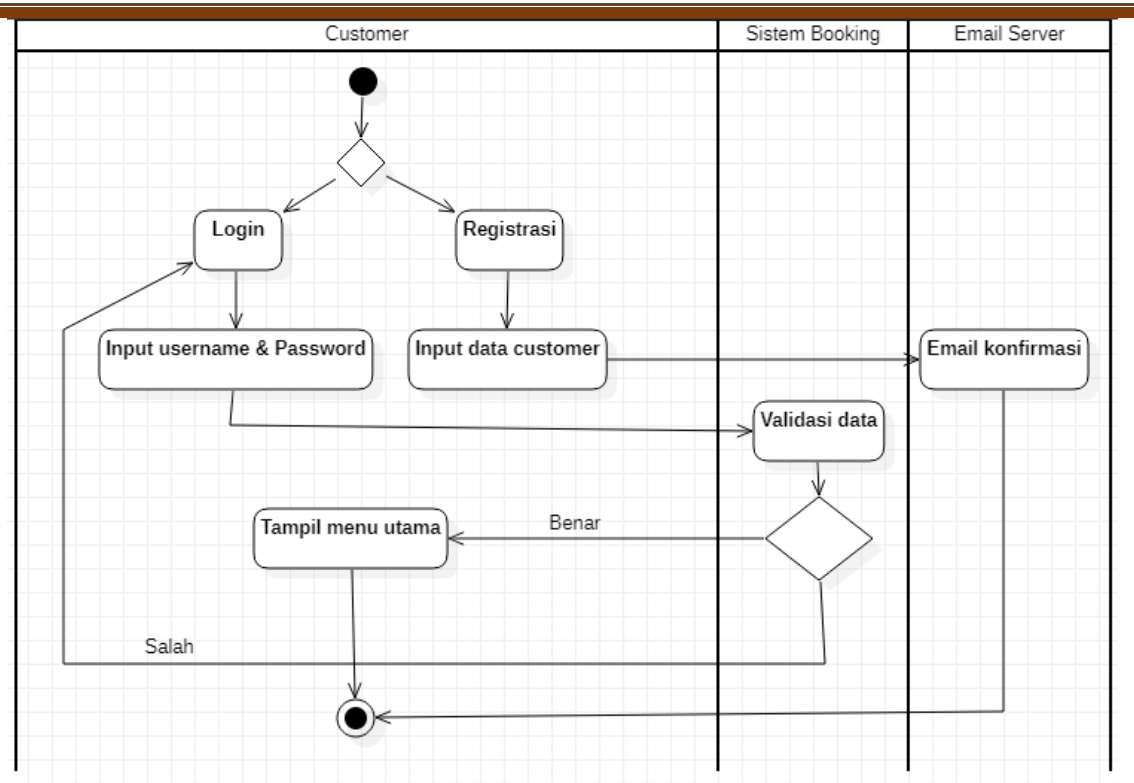

Gambar 2. Activity Diagram Login dan Registrasi

Berikut ini adalah Activity Diagram Admin dan Customer

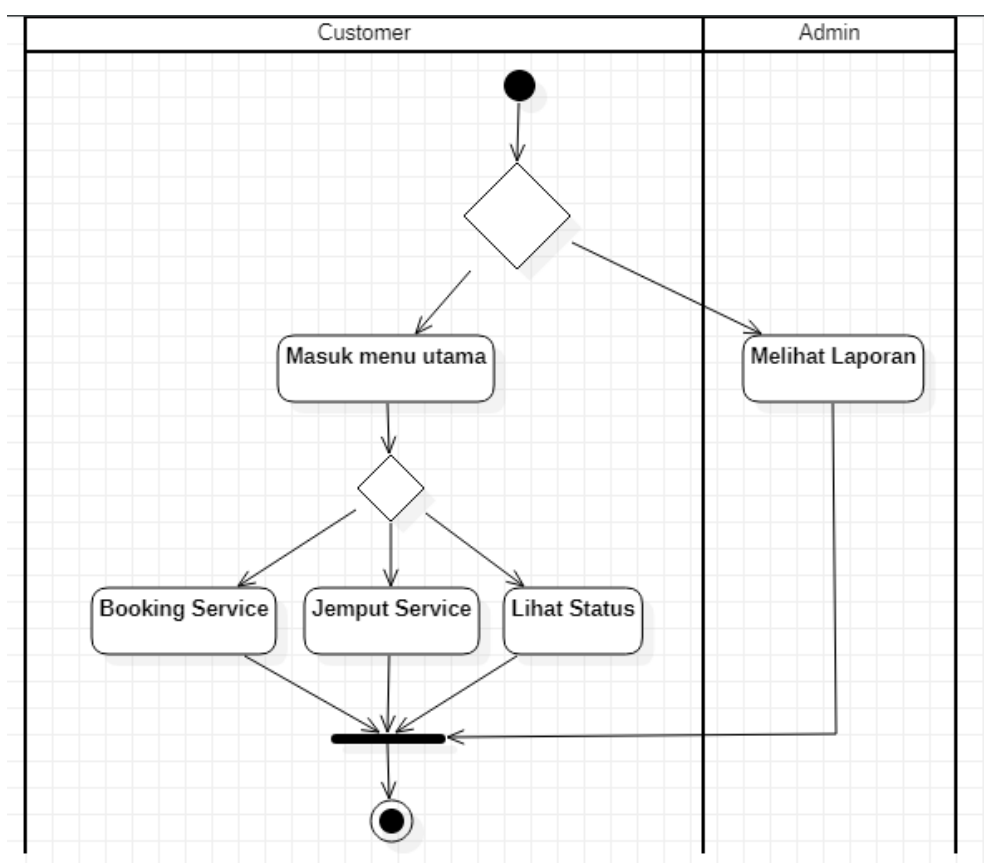

Gambar 3. Activity Diagram Admin dan Customer

Disain basis data secara konseptual dapat digambarkan dalam bentuk diagram Entity relationship berikut: 


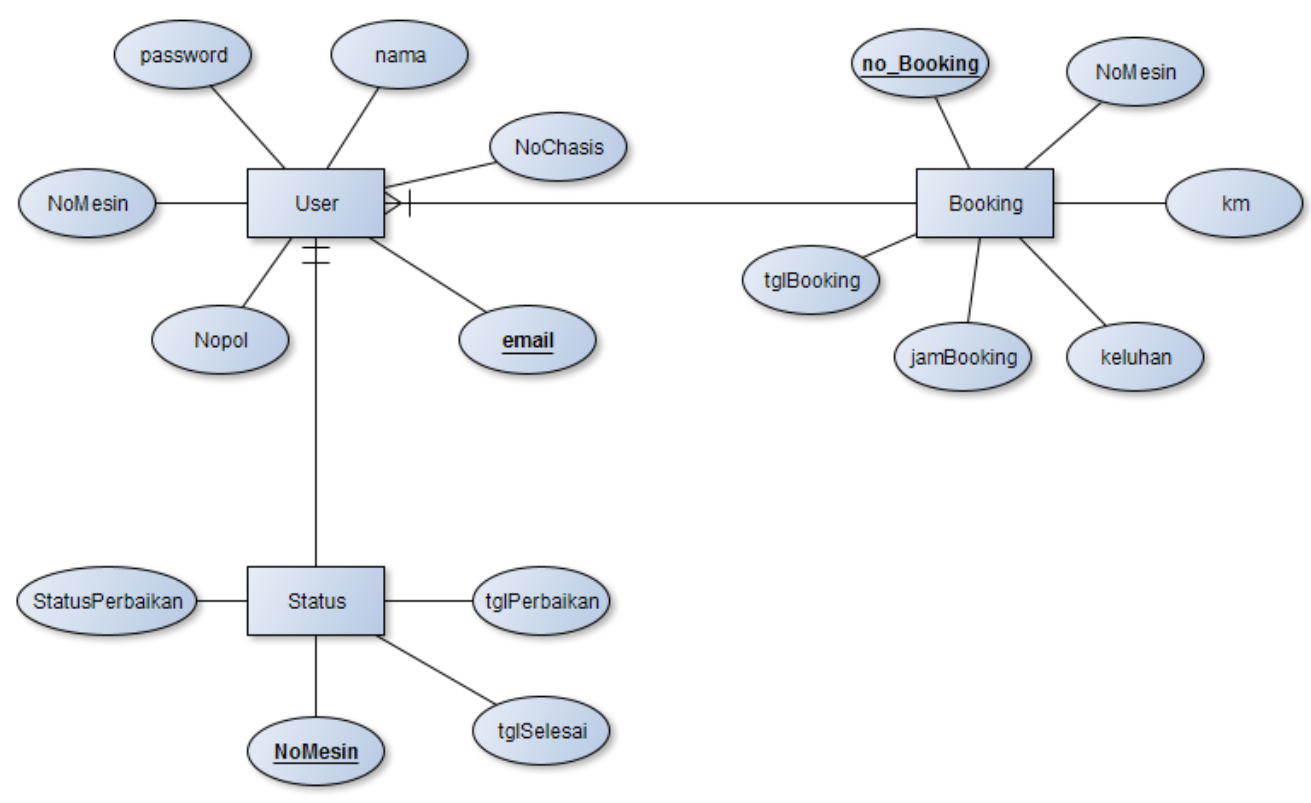

Gambar 4. Entity Relationship Diagram

Berikut ini adalah Logical Record Structure

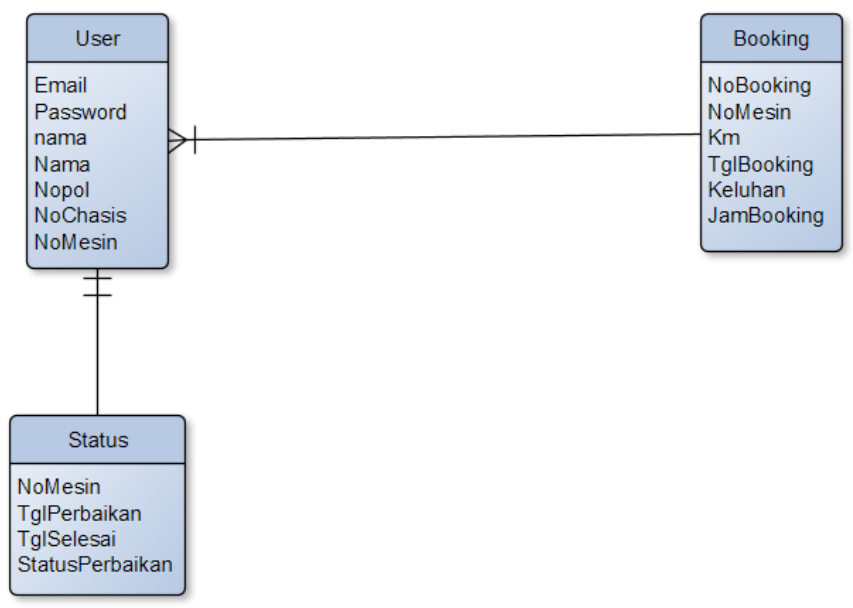

Gambar 5. Logical Record Structure

Rancangan layar atau user interface merupakan salah satu komponen dari sistem yang dirancang sebagai sarana komunikasi antara user (customer), admin dan program sistem yang nantinya akan digunakan. Berikut ini layar untuk login: 


\section{$\log$ in}

Email

admin

Password

.....

$\square$ Login as Admin

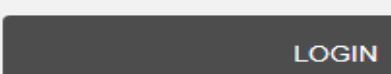

Don't have account ? Create Account

Forgot Password? Reset Password

Gambar 6. Halaman Login

Berikut ini halaman Registrasi Customer

\section{Sign Up}

Name

Enter Name *

Email

admin

Police Number

Enter Type *

VIN Number (Chassis Number)

Enter Chassis Number *

Phone Number (Mobile)

Enter Mobile Number *

Gambar 7. Halaman Registrasi 


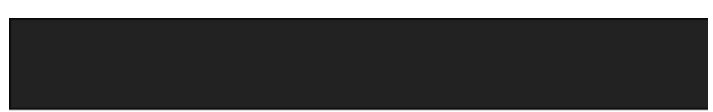

\section{Reset Password}

User Name (Email)

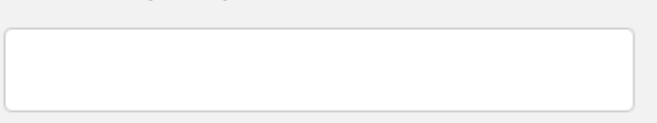

Password Baru

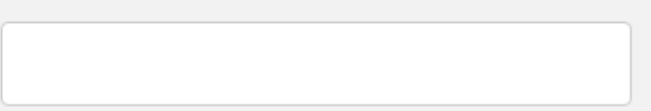

Konfirmasi Password Baru

Reset

Gambar 8. Halaman Reset Password

Berikut ini halaman Menu Utama Booking Online

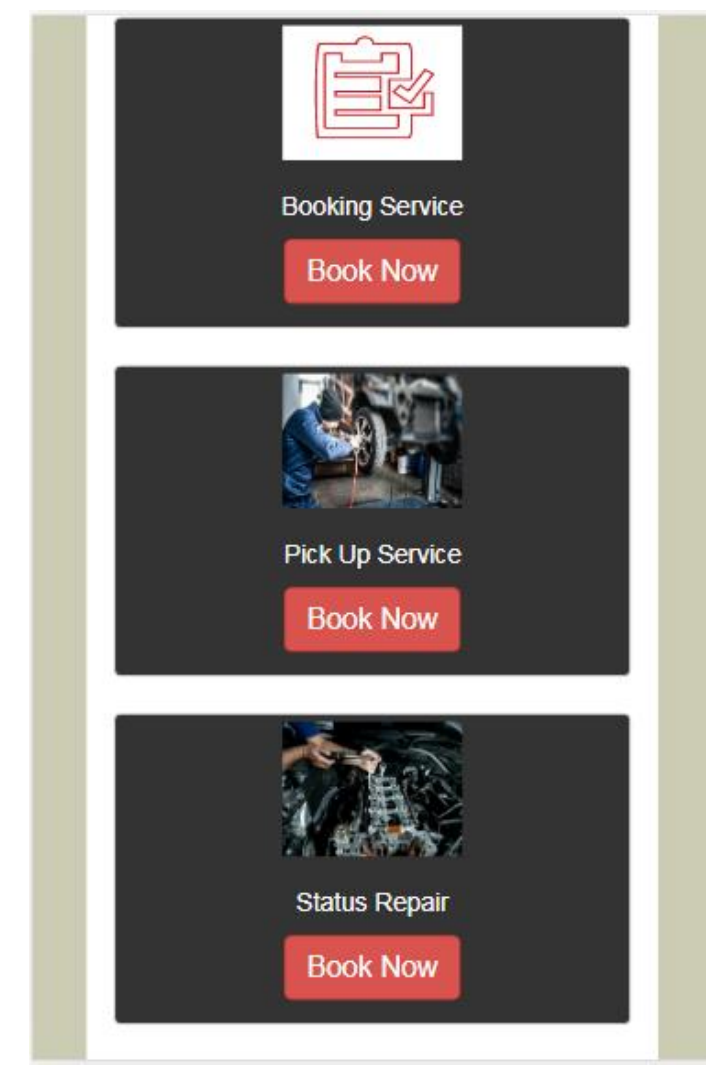

Gambar 9. Menu Booking Online 
Volume 7 No 1; Maret 2021

Berikut ini rancangan Halaman Booking Service

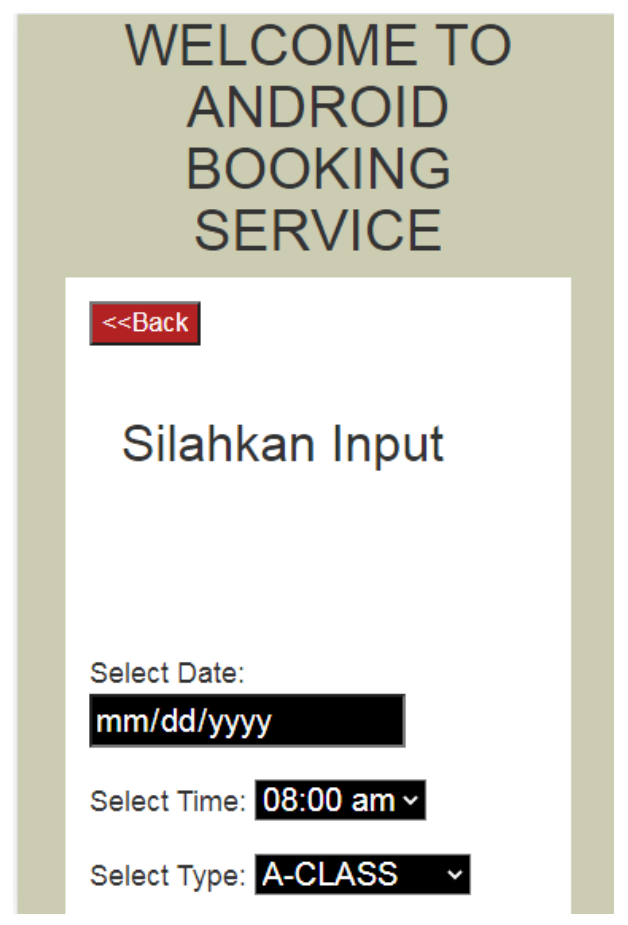

Gambar 10. Halaman Booking Service

Berikut ini rancangan Halaman Pickup Service

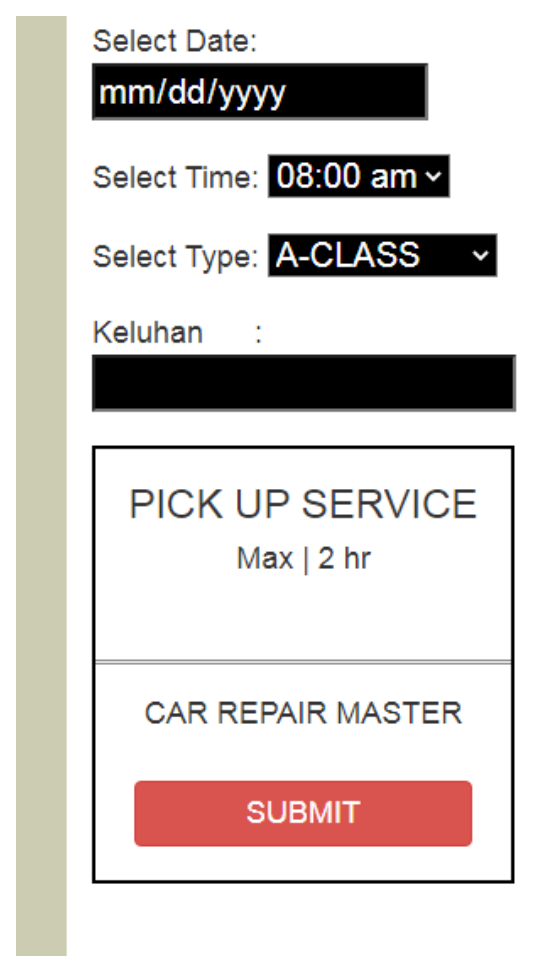

Gambar 11. Halaman Absen 


\section{KESIMPULAN DAN REKOMENDASI}

Berdasarkan hasil pengembangan dari sistem yang telah dilakukan, maka dapat diberikan kesimpulan dan beberapa rekomendasi yang berhubungan dengan pembahasan yang telah dikemukakan.

Berikut ini kesimpulan yang dapat diambil yaitu :

Dengan adanya sistem informasi booking online berbasis android sangat membantu para customer dalam melakukan booking online dimana dan kapanpun dengan cepat dan mudah. Sistem informasi berbasis android pada saat ini memang sudah menjadi kebutuhan yang tidak bisa dihindari, dan terbukti dibeberapa perusahaan yang sudah menerapkan sistem informasi pelayanan bagi customernya, yang dapat diakses melalui android maka hal tersebut dapat meningkatkan nilai tambah perusahaan di mata para customernya.

Berikut ini rekomendasi yang dapat diberikan:

Perlu dibuatkan user manual bagi para customer bagaimana menggunakan sistem informasi booking online ini. Sistem informasi berbasis android yang telah dibuat hendaknya dilakukan maintenance secara periodic dengan baik dan benar. Pentingnya backup data dalam database untuk mencegah hal hal yang tidak diinginkan.

\section{REFERENSI}

Anggraeni, E. Y., \& Irviani, R. (2017). Pengantar Sistem Informasi. (E. Risanto, Ed.). Yogyakarta.

Andi Bakhri, S. (2015). Rancang Bangun Sistem Informasi Penjualan Sembako Menggunakan Metode Waterfall, 3(1), 70-82.

Hery. (2012). Pengantar Akuntansi 1. Jakarta: Fakultas Ekonomi Universitas Indonesia.

Muslihudin, M., \& Oktafianto. (2016). Analisis dan Perancangan Sistem Informasi Menggunakan Model Terstruktur dan UML. (A. Pramesta, Ed.). Yogyakarta: Penerbit Andi.

Puspitasari, D. (2015). Rancang Bangun Sistem Informasi Koperasi Simpan Pinjam Karyawan Berbasis Web. Seminar Nasional Ilmu Pengetahuan Dan Teknologi Komputer, XI(2), 186-INF.196. 